\title{
Bridging progestogens in pregnancy and pregnancy prevention
}

\author{
Elizabeth Micks ${ }^{1}$, Greta B Raglan ${ }^{2}$ and Jay Schulkin ${ }^{1,2}$ \\ 'Department of Obstetrics and Gynecology, University of Washington, Box 356460, 1959 NE Pacific Street, Seattle, \\ Washington, USA \\ ${ }^{2}$ Department of Research, American College of Obstetricians and Gynecologists, 409 12th Street SW, Washington, \\ District of Columbia, USA
}

\author{
Correspondence \\ should be addressed \\ to E Micks \\ Email \\ emicks@uw.edu
}

\begin{abstract}
Steroid hormones have been in use for more than a half a century as contraceptive agents, and only now are researchers elucidating the biochemical mechanisms of action and non-target effects. Progesterone and synthetic progestins, critical for women's health in the US and internationally, appear to have important effects on immune functioning and other diverse systems. Apart from the contraceptive world is a separate field that is devoted to understanding progesterone in other contexts. Based on research following a development timeline parallel to hormonal contraception, progesterone and 17-hydroxyprogesterone caproate are now administered to prevent preterm birth in high-risk pregnant women. Preterm birth researchers are similarly working to determine the precise biochemical actions and immunological effects of progesterone. Progesterone research in both areas could benefit from increased collaboration and bringing these two bodies of literature together. Progesterone, through actions on various hormone receptors, has lifelong importance in different organ systems and researchers have much to learn about this molecule from the combination of existing literatures, and from future studies that build on this combined knowledge base.
\end{abstract}

\author{
Key Words \\ - progestogens \\ - pregnancy \\ - contraception \\ - preterm birth \\ collaborative research
}

\section{Introduction}

\section{Progesterone, progestins, and progestogens}

Progesterone is a C-21 steroid hormone first identified and characterized by Willard Myron Allen in 1933. C-21 steroid hormones contain 21 carbons and are also referred to as pregnanes. This class of signaling molecules also includes corticosteroids. Dr Allen named the compound progesterone, shortened from 'progestational steroid ketone'. Many different synthetic agents that bind the progesterone receptor (PR), termed 'progestins', are now used for contraception, preterm birth prevention, hormone therapy, and as treatment for a wide range of gynecologic conditions. As the number of available compounds has grown, so too has our understanding of how they differ in terms of metabolism, pharmacokinetics, potency, binding affinity for the PR and other steroid receptors, and effects on diverse cell types. The term 'progestogen' encompasses both natural and synthetic compounds that bind the PR.

\section{The need for contraceptive technology}

Half of pregnancies in the USA are unintended $(1,2,3)$. About half of women in the USA will have an unintended

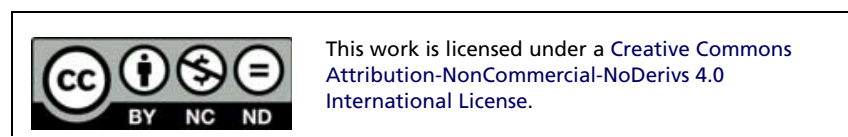


pregnancy by age 45, and one in three will have an abortion (4). Worldwide, the situation is more dire as women with unintended pregnancy often do not have access to safe abortion or obstetric care. Over 280000 maternal deaths occurred in 2010 and $7.9 \%$ were due to unsafe abortion (5). Improvements in contraceptive access as well as advancements in contraceptive technology are needed to address these issues (6). Reducing unmet need for family planning represents one of the most effective strategies for improving maternal health (7), and progestogens remain one of the most promising avenues for contraceptive research and development. However, there is evidence indicating that current methods of hormonal contraception, particularly injectable progestins, may increase women's risk of HIV acquisition and transmission to male sex partners (8). Lack of other contraceptive options, especially for women at highest risk, is a critical barrier to progress towards optimizing women's reproductive health.

\section{Progesterone for preterm birth prevention}

In 2006, progesterone and 17 $\alpha$-hydroxyprogesterone caproate (17-OHPC) re-emerged as effective therapies for pregnant women at high risk for preterm delivery (delivery at $<37$ weeks gestation). In turn, scientists studying the mechanisms of normal and preterm birth and the role of reproductive hormones made important discoveries regarding progestins, the $\mathrm{PR}$, and related steroid receptors. Research in preterm and normal labor has highlighted the impact of progesterone on immune functioning.

\section{Bringing two worlds together}

Biochemists continue to elucidate the mechanisms of action of different progestins in order to identify the safest and most effective compounds for widespread use in contraceptives and preterm birth prevention, but research in these areas tends to occur in a vacuum. Researchers in both areas would benefit from following the other separately evolving field. This article aims to bring together these two related literatures, discuss the state of the science of the physiology of progestins and progesterone for these indications, and determine what conclusions may be drawn about the differential effects of progestins on various organ systems, particularly the immune system, and how these findings might impact the development of contraceptive and preterm birth prevention methods.

\section{Progesterone: diverse roles in different systems}

It is estimated that steroid receptors first appeared in living organisms approximately half a billion years ago. The mineralocorticoid, glucocorticoid, progesterone, and androgen receptors are very closely related members of the nuclear-receptor super-family, thought to arise in multicellular animals $(9,10)$. Structurally similar receptors exist in all vertebrates, and are present in some invertebrates such as mollusks, proving their ancient origins $(11,12)$.

Progesterone has diverse effects on myriad systems. It plays a role in pair bonding in birds (13), body fluid balance in humans (14), sexual differentiation in fish (15), and sexual receptivity in mice (16). In human males and females, progesterone has been found to have various reproductive and non-reproductive functions, including immunomodulation, neuroprotection, and inhibition of cholesterol synthesis $(17,18,19)$. Progesterone is one of several hormones, including Vitamin D, aldosterone, and cortisol, which all compete for similar receptor sites in both brain and peripheral tissue. Receptor binding and subsequent effects depend on the metabolic condition (20).

The role of progesterone in reproductive functioning is complex in both pregnant and nonpregnant women. In a normal menstrual cycle, progesterone is critical for preparing the endometrium for implantation of the embryo and, if implantation occurs, it is needed to maintain the pregnancy $(21,22)$. If pregnancy does not occur, bleeding occurs in response to progesterone withdrawal. Progesterone also is responsible for ovulation suppression during the luteal phase. In pregnant women, progesterone promotes uterine quiescence but, through different receptors, also makes a contribution to the cascade of events leading to labor (23).

\section{Diverse signaling pathways}

Progesterone was traditionally believed to act only through the progesterone and other steroid receptors via gene transcription and translation of genes into proteins. The PR is one of the best-described transcription factors. However, it also acts through many non-genomic mechanisms that do not require steroid receptors and protein transcription. Such actions are considerably faster and may play crucial roles in several organ systems, especially the brain. Non-genomic actions of progesterone include activation of intracellular signaling pathways through modulation of cell surface receptors, ion channels, and secondary messenger cascades (24). Through these This work is licensed under a Creative Commons
Attribution-NonCommercial-NoDerivs 4.0 International License. 
mechanisms, as well as the traditional PR pathway, progesterone helps regulate cell viability in the brain. Other examples of rapid non-genomic effects include acceleration of oocyte maturation and stimulation of the acrosomal reaction in spermatozoa (25). Some of these effects are mediated through a different kind of PR, sometimes referred to as 'membrane PRs', which may act via inhibitory G-proteins (26).

\section{Progestins in pregnancy}

\section{Biochemical effects of progesterone in normal pregnancy}

In humans and some primates, unlike other mammals, labor is not precipitated by systemic withdrawal of progesterone. Rather, a so-called functional withdrawal of progesterone occurs prior to term or preterm labor due to mechanisms including increased catabolism and changes in availability and type of PRs (27). Furthermore, inhibition of corticotropin-releasing hormone (CRH) in both the brain and placenta, and antagonism with the transcription factor nuclear factor-kappa $\mathrm{B}(\mathrm{NF} \kappa \mathrm{B})$ are also important mechanisms that account for the efficacy of progesterone in the prevention of preterm labor (19).

Studies have examined the presence of various PRs within the myometrium at different stages in pregnancy (28). In myometrial samples taken at the onset of labor, there is a change in the ratio of two different PRs (PR-A and PR-B), leading to differential activation of progesteroneresponsive genes. This enables progesterone to have very different effects during this period of time compared to its effects during earlier stages of pregnancy. Recent evidence suggests that myometrial cells are PR-B dominant through most of pregnancy and promote a quiescent state through anti-inflammatory actions. When labor occurs, PR-A expression rises and allows progesterone to stimulate pro-inflammatory gene expression, and inhibit the anti-inflammatory actions of PR-B (23). Furthermore, PR co-activators decrease significantly in normal term pregnancy and during labor. These changes make the myometrium more sensitive to contractile stimuli and are key to labor timing in humans (27).

Placental expression of CRH is also a key determinant of steroid hormone production and gestational length in humans. The placenta produces $\mathrm{CRH}$, which increases exponentially in pregnancy, leading to increased cortisol production by the fetal adrenal glands, as well as direct effects on the myometrium, decidua, and amnion. $\mathrm{CRH}$ levels are strongly associated with birth timing. Progesterone interacts with placental CRH in complex ways $(19,29)$; it both inhibits $\mathrm{CRH}$ production in the placenta and attenuates the effects of CRH. Progesterone also competes with cortisol for the same receptor sites. The effect of progesterone on CRH activity depends on gestational age and the ratio of different PRs.

The role of progesterone in pregnancy maintenance and in labor initiation is complex and varies throughout pregnancy depending on the state of myometrial receptors and other factors. Nonetheless, clear evidence for the importance of progesterone in pregnancy maintenance comes from the known effects of selective PR modulators (SPRMs). This class of medications includes mifepristone, with primarily antagonistic effects, and ulipristal acetate, with tissue selective mixed agonist and antagonist activity (30). Mifepristone is highly effective for pregnancy termination, particularly in a regimen combined with the prostaglandin analog misoprostol (31). Ulipristal acetate is used for emergency contraception up to 5 days after unprotected intercourse. It reliably inhibits ovulation as a primary mechanism of action but also promotes endometrial effects that prevent implantation of an embryo (32).

\section{Progesterone and the prevention of preterm labor}

In the 1950s, when the first progestins were synthesized for contraceptive use, progesterone and the natural adrenal progestogen $17 \alpha$-hydroxyprogesterone (17-OHP) were initially used to prevent spontaneous abortion. Early studies failed to show that this practice was beneficial $(33,34)$. In 1951 and 1954 studies by Eichner, women who had preterm premature rupture of membranes were given progesterone to delay the onset of labor $(33,34,35,36)$. In 1960, in a study by Fuchs, large doses of progesterone were administered to women to treat threatened preterm labor (37). These trials, however, were largely unsuccessful. Later, it was found that in order to prolong pregnancy duration, progesterone must be administered long before clinical preterm labor (38).

In the obstetric setting, studies have almost exclusively evaluated natural progesterone and progestogens for their effects on preterm birth due to concerns regarding fetal exposure. In early studies, synthetic progestins, but not natural progesterone, were found to have either a feminizing or virilizing effect on children who were exposed in utero (39). In doses higher than those currently used in practice, natural progesterone exposure in utero has been associated with behavioral changes and slightly delayed sexual maturation. Other studies have suggested an increased risk of hypospadias among male offspring of
This work is licensed under a Creative Commons Attribution-NonCommercial-NoDerivs 4.0 International License. 
women using progesterone in early pregnancy $(40,41)$. However, this is not a major concern for women using progesterone for prevention of preterm labor, as the therapy does not begin until at least 16 weeks' gestation.

17-OHPC, the synthetic ester derivative of 17-OHP formed from caproic acid, is the major progestin used today to prevent recurrent preterm birth among women with a prior preterm delivery $(38,42)$. Several reviews and meta-analyses have summarized the clinical trials evaluating progesterone for the prevention of preterm labor $(43,44)$. Modern obstetrical practice shifted towards the use of progesterone in high-risk women after the publication of two large randomized trials in $2003(38,45)$. The Meis study found that weekly i.m. injection of 17-OHPC significantly decreased the percentage of preterm deliveries among women with singleton pregnancies who had a history of prior spontaneous preterm birth. The relative risk with 17-OHPC for preterm delivery at $<37$ weeks was 0.66 (0.54-0.81), $P<0.001$. This same regimen has not been effective in several studies of women with twin or triplet pregnancies $(46,47,48)$. Oral micronized progesterone has also been shown to be effective among women with singleton pregnancies who have a prior spontaneous preterm birth. In one study, 29/74 women in the oral progesterone group vs $44 / 79$ women in the placebo group had a preterm delivery at $<37$ weeks $(P=0.002)$ (49). Decreased risk of preterm delivery has been achieved with vaginal progesterone gel, though one study showed no effect (50).

Natural progesterone is vaginally administered to prevent preterm birth among women at risk due to sonographically diagnosed short cervix (51). In a large study using vaginal micronized progesterone capsules, the risk of preterm birth $<34$ weeks among women with cervical length of $15 \mathrm{~mm}$ or less between 20 and 25 weeks gestation was $19 \%$ vs $34 \%$ in the placebo group (relative risk (RR) $0.56,0.36-0.86, P=0.02$ ) (51). Similar results were observed in another study of vaginal progesterone in women with a short cervix measuring $10-20 \mathrm{~mm}$ at enrollment (52). A more recent study concluded that vaginal progesterone was equally effective as cerclage in this setting (53). As with 17-OHPC, vaginal progesterone has not been shown to be effective in twin pregnancies $(54,55)$.

The immunological effects of 17-OHPC and natural progesterone appear to play a major role in birth timing. Progesterone inhibits the transcription factor $\mathrm{NF \kappa B}$, inhibiting COX2 and the production of prostaglandins, which are known to promote labor $(56,57)$. NFkB is stimulated by pro-inflammatory cytokines including tumor necrosis factor alpha (TNF $\alpha)$, lipopolysaccharides, and interleukin 1 beta (IL1 $\beta$ ). Conversely, NFאB promotes the synthesis of cytokines, and additionally increases expression of the oxytocin receptor and inhibitory PR isoforms (19). Pretreatment of reproductive tissues with progesterone appears to decrease cytokine-mediated inflammation $(58,59)$. In a large preterm birth study, women with singleton pregnancies who received 17-OHPC had decreased IL1 $\beta$ noted on cervical swabs and decreased cervical shortening (60). Thus progesterone exhibits anti-inflammatory effects that help to inhibit labor onset.

Treatment with 17-OHPC or progesterone appears to significantly reduce the risk of spontaneous preterm birth among high-risk women and decrease the risk of perinatal morbidity. The treatment has few adverse effects. As with certain progestin contraceptives, the only contraindications are hormone-sensitive cancers, active liver disease, and uncontrolled hypertension (61). The most common side effects are injection site reactions for 17-OHPC, and vaginal irritation for vaginally-administered progesterone $(38,48)$. Studies have not consistently shown any increased risks of adverse pregnancy outcomes such as stillbirth, gestational diabetes, or fetal anomalies (62).

While progesterone treatment appears to have an important place in obstetric practice, the exact biochemical mechanisms of action are not known. Progesterone has anti-inflammatory effects in the normal physiology of pregnancy and labor, but supplemental progesterone has inconsistent effects and has not proven to be beneficial in some settings such as multiple gestations. One study demonstrated that subjects with twin pregnancy who received 17-OHPC had higher levels of C-reactive protein and delivered at an earlier gestational age (47). Use of 17-OHPC and progesterone for preterm labor prevention has been shown to be effective in some clinical settings, but further research is needed to determine why progesterone therapy does not universally lead to increased length of gestation.

\section{Progestins in contraception}

\section{The development of progestins for contraception}

Figure 1 illustrates the timeline for development of progestin contraceptives. In the 1920s, scientists observed that steroid extracts administered to animals inhibited fertility. In 1942, Russell Marker identified a technique to convert diosgenin, a steroid precursor, from Mexican yams into progesterone. Carl Djerassi later developed an efficient technique to synthesize large volumes of steroid
This work is licensed under a Creative Commons Attribution-NonCommercial-NoDerivs 4.0 International License. 


\begin{tabular}{|c|}
\hline $\begin{array}{c}\text { Observation that progesterone administration inhibited fertility } \\
\text { in animals }\end{array}$ \\
\hline $\begin{array}{c}\text { Progesterone recognized as important for implantation and } \\
\text { maintenance of pregnancy }\end{array}$ \\
\hline Russel Marker identifed technique to convert diosgenin into progesterone \\
\hline First contraceptive pill is approved by the FDA \\
\hline Carl Djerassi developes norethindrone and noethynodrel, the synthesize large quanities for medical use \\
first two synthetic progetins
\end{tabular}

\section{Figure 1}

A timeline of the history of progesterone development.

hormones using microbiologic fermentation. He also found that more pronounced progestational activity occurred after the removal of the 19-carbon of yamderived progesterone. This led to the development of norethindrone and norethynodrel, the first two synthetic progestins allowing for further studies of progesterone in pregnancy and contraception.

Oral progestin products were initially contaminated with mestranol, a form of estrogen. Subsequent clinical trials indicated that women experienced unscheduled bleeding (bleeding which occurs during use of active hormones) when purer progestin was administered, and thus estrogen was added to the first oral contraceptive pill (OCP) approved for use in 1960. In the decade following its approval, the estrogen-progestin OCP was found to confer an increased risk of thrombosis and death. These rare but serious risks led to efforts to decrease the estrogen dose in contraceptive products or eliminate the estrogen altogether. There has since been successful development of both short- and long-acting effective progestin-only contraceptives.

\section{Differences in contraceptive progestins}

Removal of the 19-carbon in natural progesterone to develop a more potent synthetic progestational agent was an early breakthrough in steroid hormone bioengineering. Many new progestins have been developed since the advent of norethindrone and norethynodrel. In general, the aim is to develop compounds that have stronger effects, particularly on the ovary and endometrium, and that have improved safety and menstrual cycle control, reduced side effects, and desirable noncontraceptive benefits. http://www.endocrineconnections.org DOI: 10.1530/EC-15-0093
(C) 2015 The authors Published by Bioscientifica Ltd.
This work is licensed under a Creative Commons Attribution-NonCommercial-NoDerivs 4.0 International License. 
Progestin compounds display differing binding affinities to the PR, androgen receptor, estrogen receptor, glucocorticoid receptor, and mineralocorticoid receptor. Currently available contraceptive progestins are related to either natural testosterone or progesterone (Fig. 2) (63). The 19-nortestosterone derivatives include 13-methylgonanes such as levonorgestrel and desogestrel, and estranes such as norethindrone and norethynodrel. Two antiandrogenic progestins, dienogest and drospirenone, are both structurally related to testosterone, but lack an ethinyl group at carbon 17 . The progestins that are structurally related to progesterone include the 17-hydroxyprogesterone derivatives (pregnanes), or 19-norprogesterone derivatives (norpregnanes).

Because divisions according to chemical structure do not necessarily correlate with differences in biological activity, progestins are more often grouped according to when they were developed. First and second generation progestins such as medroxyprogesterone acetate (MPA), levonorgestrel, and norethindrone are potent PR agonists, but also target other steroid receptors in undesirable ways. Norethindrone and levonorgestrel are androgenic while MPA binds to the glucocorticoid receptor (64), potentially leading to negative effects on bone density and immune functioning. Third and fourth generation progestins have been designed to have strong progestational activity while lacking androgenic activity. Some, such as drospirenone and cyproterone acetate, have anti-androgenic and antimineralocorticoid activity, possibly leading to desirable non-contraceptive benefits in certain patients (65). Most data regarding the differences between different progestins are from in vitro biochemical studies. Further studies are needed to determine whether these translate to actual clinical differences.

\section{Current progestin methods: mechanism of action and efficacy}

Historically, ovulation suppression was the major goal for contraceptives. In higher doses, progestin methods provide reliable suppression of ovulation. Methods such as injectable depot medroxyprogesterone acetate (DMPA), combined OCPs, and the subdermal implant all have this effect. Low-dose progestin-only pills and the levonorgestrel intrauterine system (LNG-IUS), however, do not provide sufficient amounts of progestin for consistent ovulation suppression and rely instead on cervical and endometrial effects for contraceptive efficacy (66).

Cervical mucus thickening, possibly along with other cervical changes, is believed to be a major mechanism of action of all progestin methods of contraception, including the LNG-IUS (67). Rapid changes in cervical mucus

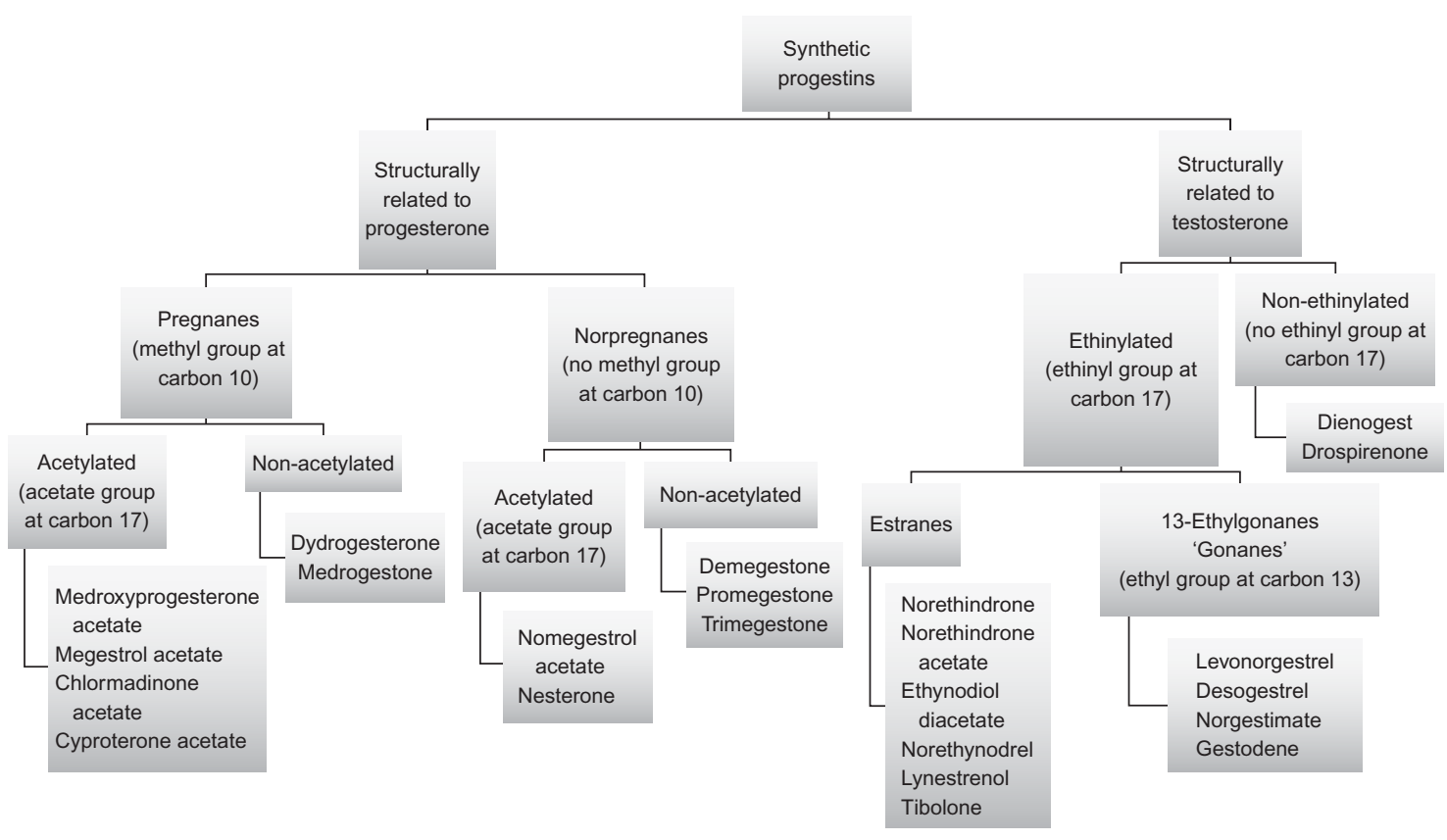

Figure 2

Classification of synthetic progestins. Reprinted from Edelman AB, Cherala G \& Stanczyk FZ 2010 Metabolism and pharacokinetics of contaceptive steroids in obese women: a review. Contraception 82 314-323, with permission from Elsevier.

This work is licensed under a Creative Commons Attribution-NonCommercial-NoDerivs 4.0 International License. 
consistency occur within hours of progestin administration (68). Changes in tubal motility, sperm motility, and egg penetrability are also observed in response to progesterone within the female reproductive tract $(69,70,71)$.

All hormonal methods of contraception are progestincontaining. Some also have an estrogen component, including the OCP, contraceptive patch, and contraceptive vaginal ring. It is the progestin component, however, that is primarily responsible for contraceptive efficacy (61). Hormonal contraceptives are variable in terms of route of administration and frequency of administration. Contraceptive pills (both progestin-only, and combined estrogen and progestin) require daily use, whereas the transdermal patch is placed weekly, and the vaginal ring is placed monthly. These methods are highly effective with perfect use, but in practice low compliance and continuation lead to an annual failure rate of $9 \%$ for the pill, patch, and vaginal ring (72).

Long-acting hormonal methods that are not userdependent (requiring placement and removal by a healthcare provider) such as the subdermal implant and LNG-IUS have failure rates of $<1 \%(72,73)$, making them some of the most effective contraceptive strategies available. They are also effective for years (up to 3 years for the etonogestrel implant and up to 5 years for the LNG-IUS). Through IUDs, local paracrine effects of progestins on the cervix and endometrium lead to arguably higher contraceptive efficacy than systemic oral, transdermal, and vaginal progestins, or other combined progestin/estrogen contraceptives (74). This efficacy may be reinforced due to the nature of the delivery system that mostly eliminates the possibility of noncompliance or user error.

The bleeding profile and hormonal side effects of the LNG-IUS and contraceptive implants have led to high discontinuation rates in some studies $(75,76)$. However, the necessity of a trained provider for insertion may be the primary deterrent to use with both insertion and removal proving challenging for patients with scant access to health care. Ease of insertion and removal, and high costs have limited the availability of these effective methods in resource-poor areas $(77,78,79,80,81)$.

The progestin levonorgestrel is also widely used for emergency contraception. The current regimen of $1.5 \mathrm{mg}$ orally as a one-time dose is FDA-approved for use within $72 \mathrm{~h}$ after unprotected intercourse, though there is evidence that it is still effective for up to 5 days. The failure rate is $\sim 2-3 \%$ (79). Levonorgestrel appears to be less effective than the copper intrauterine device (IUD) and the SPRM ulipristal acetate for emergency contraception, and it may not be effective in overweight and obese women. The main mechanism of action is delayed ovulation. There is no evidence that levonorgestrel is effective for emergency contraception after ovulation has occurred (80).

Unscheduled 'breakthrough' bleeding is the most common side effect with progestin-only contraceptives, and frequently leads to early discontinuation of these methods (76). Unscheduled bleeding refers to vaginal bleeding during active hormone use, as opposed to the scheduled bleeding occurring during hormone-free periods, such as during the placebo week of OCPs. Initial use of DMPA, the etonogestrel implant, progestin-only pills, and the LNG-IUS are associated with frequent bleeding episodes, often for 6 months or longer, and unpredictable bleeding can also continue to occur throughout use of these products. Decreasing the length of this so-called 'adjustment period' is an active area of research. Mifepristone, estrogen, and other hormonal and nonhormonal medications are all potential means to improve the bleeding profile of progestin methods $(81,82,83)$.

Adverse effects of progestin-containing contraceptives can include bone density loss with prolonged use of DMPA (84), increased risk of HIV transmission among users of injectable contraception (85), decreased insulin sensitivity, and possible increased heart disease and breast cancer risk in menopausal hormone therapy users $(86,87,88,89)$. The only contraindication for all progestin methods of contraception is a history of breast cancer (90). Some methods are also contraindicated in active liver disease and uncontrolled hypertension. However, many positive effects of progestin contraceptives exist including markedly decreased risk of endometrial cancer (91), decreased menstrual blood loss, and decreased dysmenorrhea (92).

Progestin-containing contraceptives are safe and highly effective for pregnancy prevention (72). Different delivery systems with either systemic or primarily local effects, as well as newer progestins, have led to greater choices for patients and physicians. Continued development and improvement upon current contraceptive methods could provide safer, easier to use, and more effective drugs and devices, which may decrease unintended pregnancies.

\section{Immunological effects of contraceptive progestins}

Progesterone plays a critical role in immune functioning within the female reproductive tract. Early studies of PR knockout mice found evidence for a strong anti-inflammatory effect, particularly in the presence of estrogen (93). Further studies have determined that certain progestins 
can exhibit immunological effects by binding to different types of receptors, particularly the glucocorticoid receptor.

MPA binds to the glucocorticoid receptor with greater affinity than any other progestin, and with greater affinity than even cortisol. MPA has been shown to suppress human cytokine production, leading to anti-inflammatory and immunosuppressive properties. The link between injectable progestins (notably DMPA) and HIV transmission has accelerated research on progestins, particularly MPA, and immune modulation (85). A recent study showed that DMPA administered to mice infected with tuberculosis led to decreased cytokine levels (TNF $\alpha$, IL6, IL10, and G-CSF) (94). Furthermore, DMPA-treated mice infected with tuberculosis had a higher bacterial load in their lungs, suggesting that the contraceptive can affect disease severity. Another recent study found that contraceptive doses of MPA enhanced the depletion of CD4+ T-cells through actions on the glucocorticoid receptor, similar to cortisol and dexamethasone (95). Norethisterone (a second generation progestin) and progesterone did not have this effect. Interestingly, asthma symptoms may be decreased among women taking OCPs, possibly related to effects on T-cell functioning (96).

These findings suggest that choice of progestin for contraception might affect HIV susceptibility and progression. A study by Africander et al. (97) found that MPA decreased expression of the pro-inflammatory RANTES gene through actions on the androgen receptor within cells of the ectocervix, but up-regulated this same gene in vaginal epithelial cells. In contrast, progesterone was found to up-regulate the expression of RANTES as well as the inflammatory cytokines IL6 and IL8 in both cell types.

While glucocorticoid receptor agonist activity by progestins such as MPA has negative effects on the immune system, the literature is inconsistent with regards to natural progesterone and its affinity for the glucocorticoid receptor. Though newer progestins are being designed to more closely resemble progesterone, it is not known precisely what effect this natural compound has on the immune system at contraceptive doses. Effects vary according to which cell type is being studied. Furthermore, it is unknown whether immunologic effects of synthetic progestins are due solely to their binding to the glucocorticoid receptor, or whether these effects could be mediated by binding to the PR itself. Obstetrics research has illustrated that progesterone works by suppressing the inflammatory signals that lead to myometrial contractions and preterm labor. This effect is mediated through the PR.

\section{Conclusions}

In evaluating the effects of contraceptive progestins, we can look at the effects of pregnancy, a naturally high progesterone state. The resurgence of progesterone for the prevention of preterm birth has provided a wealth of new research in this area, and has provided new insights into the effects of exogenous progesterone. In addition, contraception research can provide important information for the study of progestins in the context of pregnancy progression and preterm birth. We now know more about progesterone than ever. By bringing these two literatures together, it is possible for further connections to be made that could benefit patients at risk of preterm birth and those who wish to prevent pregnancy.

As biochemical pathways of progestin effects are revealed, we have an opportunity to develop novel compounds that may be more effective and specifically targeted, with fewer adverse effects. New drugs and devices could provide better options for patients that minimize risks and maximize therapeutic outcomes. For instance, we may be also able to design contraceptive agents that have minimal immunological effects, or engineer progestins that target only PR-B to promote uterine quiescence regardless of the ratio of myometrial receptor populations.

A better understanding of the interaction between proinflammatory and anti-inflammatory signaling pathways in different tissues and organ systems may provide insight into the mechanisms of action and nontarget effects of these compounds. For instance, are there different types of PRs within the cervix compared to the vagina and endometrium that lead to differential expression of inflammatory markers? Similarly, preterm birth researchers might benefit from the approach taken by contraceptive researchers: If the pro-inflammatory pathways during labor are mediated through a specific type of PR, perhaps a compound can be designed to provide targeted blockade of this pathway.

These are only a few examples of areas in which ongoing research regarding progestin in contraception and preterm birth prevention may inform each other. Future studies in each area will likely continue to inform the other field, and may open new avenues for study and cooperation. Future research evaluating progestins should take into account the work in both contraception and preterm birth prevention in order to explore these, and hitherto unposed questions.

Declaration of interest

The authors declare that there is no conflict of interest that could be perceived as prejudicing the impartiality of this review. 


\section{Funding}

This work was supported by the Maternal and Child Health Bureau (Title V, Social Security Act, Health Resources and Services Administration, and Department of Health and Human Services (HHS)) (grant number UA6MC19010).

\section{Author contribution statement}

E Micks conceived the idea for this work and was the primary author. She reviewed and edited the manuscript and approved the final version. G B Raglan contributed to the writing, formatting, and organization of this work. She reviewed and edited the manuscript and approved the final version. J Schulkin assisted in the conception and writing of this project. He reviewed and edited the manuscript and approved the final version.

\section{References}

1 Kost K, Finer LB \& Singh S. Variation in state unintended pregnancy rates in the United States. Perspectives on Sexual and Reproductive Health 201244 57-64. (doi:10.1363/4405712)

2 Finer LB \& Sonfield A. The evidence mounts on the benefits of preventing unintended pregnancy. Contraception 201387 126-127. (doi:10.1016/j.contraception.2012.12.005)

3 Finer LB \& Zolna MR. Shifts in intended and unintended pregnancies in the United States, 2001-2008. American Journal of Public Health 2014 104 S43-S48. (doi:10.2105/AJPH.2013.301416)

4 Henshaw SK. Unintended pregnancy in the United States. Family Planning Perspectives 199830 24-29. (doi:10.2307/2991522)

5 Say L, Chou D, Gemmill A, Tunçalp Ö, Moller A, Daniels J, Gülezoglu AM, Temmerman M \& Alkema L. Global causes of maternal death: a WHO systematic analysis. Lancet. Global Health 20142 e323-e333. (doi:10.1016/S2214-109X(14)70227-X)

6 Bergevin Y, Fauveau V \& McKinnon B. Towards ending preventable maternal deaths by 2035. Seminars in Reproductive Medicine 201533 23-29. (doi:10.1055/s-0034-1395275)

7 Jacobstein R, Curtis C, Spieler J \& Radloff S. Meeting the need for modern contraception: effective solutions to a pressing global challenge. International Journal of Gynaecology and Obstetrics 2013121 (Suppl 1) S9-15. (doi:10.1016/j.ijgo.2013.02.005)

8 Polis CB \& Curtis KM. Use of hormonal contraceptives and HIV acquisition in women: a systematic review of the epidemiological evidence. Lancet. Infectious Diseases 201313 797-808. (doi:10.1016/ S1473-3099(13)70155-5)

9 Baker ME, Funder JW \& Kattoula SR. Evolution of hormone selectivity in glucocorticoid and mineralocorticoid receptors. Journal of Steroid Biochemistry and Molecular Biology 2013137 57-70. (doi:10.1016/ j.jsbmb.2013.07.009)

10 Ellmann S, Sticht H, Thiel F, Beckmann MW, Strick R \& Strissel PL. Estrogen and progesterone receptors: from molecular structures to clinical targets. Cellular and Molecular Life Sciences 200966 2405-2426. (doi:10.1007/s00018-009-0017-3)

11 Baker ME. Steroid receptor phylogeny and vertebrate origins. Molecular and Cellular Endocrinology 1997135 101-107. (doi:10.1016/S03037207(97)00207-4)

12 Thornton JW, Need E \& Crews D. Resurrecting the ancestral steroid receptor: ancient origin of estrogen signaling. Science $2003 \mathbf{3 0 1}$ 1714-1717. (doi:10.1126/science.1086185)

13 Smiley KO, Vahaba DM \& Tomaszycki ML. Behavioral effects of progesterone on pair bonding and partner preference in the female zebra finch (Taeniopygia guttata). Behavioural Processes 201290 210-216. (doi:10.1016/j.beproc.2012.01.008)
14 Forsling ML, Stromberg P \& Akerlund M. Effect of ovarian steroids on vasopressin secretion. Journal of Endocrinology 198295 147-151. (doi:10.1677/joe.0.0950147)

15 Feist G, Schreck CB, Fitzpatrick MS \& Redding JM. Sex steroid profiles of coho salmon (Oncorhynchus kisutch) during early development and sexual differentiation. General and Comparative Endocrinology 199080 299-313. (doi:10.1016/0016-6480(90)90174-K)

16 Bonthuis PJ, Patteson JK \& Rissman EF. Acquisition of sexual receptivity: roles of chromatin acetylation, estrogen receptor- $\alpha$, and ovarian hormones. Endocrinology 2011152 3172-3181. (doi:10.1210/ en.2010-1001)

17 Amir D \& Fessler DM. Boots for Achilles: progesterone's reduction of cholesterol is a second-order adaptation. Quarterly Review of Biology 201388 97-116. (doi:10.1086/670528)

18 Deutsch ER, Espinoza TR, Atif F, Woodall E, Kaylor J \& Wright DW. Progesterone's role in neuroprotection, a review of the evidence. Brain Research 20131530 82-105. (doi:10.1016/j.brainres.2013.07.014)

19 Vrachnis N, Malamas FM, Sifakis S, Tsikouras P \& Iliodromiti Z. Immune aspects and myometrial actions of progesterone and $\mathrm{CRH}$ in labor. Clinical \& Developmental Immunology 20122012 937618. (doi:10. $1155 / 2012 / 937618)$

20 Kowalik MK, Rekawiecki R \& Kotwica J. The putative roles of nuclear and membrane-bound progesterone receptors in the female reproductive tract. Reproductive Biology 201313 279-289. (doi:10.1016/ j.repbio.2013.09.001)

21 Graham JD \& Clarke CL. Physiological action of progesterone in target tissues. Endocrine Reviews 199718 502-519. (doi:10.1210/edrv.18.4.0308)

22 Salehnia M \& Zavareh S. The effects of progesterone on oocyte maturation and embryo development. International Journal of Fertility \& Sterility 20137 74-81.

23 Tan H, Yi L, Rote NS, Hurd WW \& Mesiano S. Progesterone receptor-A and -B have opposite effects on proinflammatory gene expression in human myometrial cells: implications for progesterone actions in human pregnancy and parturition. Journal of Clinical Endocrinology and Metabolism 201297 E719-E730. (doi:10.1210/jc.2011-3251)

24 Singh M, Su C \& Ng S. Non-genomic mechanisms of progesterone action in the brain. Frontiers in Neuroscience 20137 159. (doi:10.3389/ fnins.2013.00159)

25 Leonhardt SA, Boonyaratanakornkit V \& Edwards DP. Progesterone receptor transcription and non-transcription signaling mechanisms. Steroids 200368 761-770. (doi:10.1016/S0039-128X(03)00129-6)

26 Moussatche P \& Lyons TJ. Non-genomic progesterone signalling and its non-canonical receptor. Biochemical Society Transactions 201240200 204. (doi:10.1042/BST20110638)

27 Mesiano S, Wang Y \& Norwitz ER. Progesterone receptors in the human pregnancy uterus: do they hold the key to birth timing? Reproductive Sciences 201118 6-19. (doi:10.1177/1933719110382922)

28 Sfakianaki AK \& Norwitz ER. Mechanisms of progesterone action in inhibiting prematurity. Journal of Maternal-fetal \& Neonatal Medicine 200619 763-772. (doi:10.1080/14767050600949829)

29 Smith R \& Nicholson RC. Corticotrophin releasing hormone and the timing of birth. Frontiers in Bioscience 200712 912-918. (doi:10.2741/2113)

30 Whitaker L, Williams A \& Critchley H. Selective progesterone receptor modulators. Current Opinion in Obstetrics \& Gynecology 201426 237-242. (doi:10.1097/GCO.0000000000000082)

31 Chen MJ \& Creinin MD. Mifepristone with buccal misoprostol for medical abortion: a systematic review. Obstetrics and Gynecology 2015 126 12-21. (doi:10.1097/AOG.0000000000000897)

32 Glasier A. The rationale for use of Ulipristal Acetate as first line in emergency contraception: biological and clinical evidence. Gynecological Endocrinology 201430 688-690. (doi:10.3109/09513590. 2014.950645)

33 Reifenstein EC Jr. Clinical use of $17 \alpha$-hydroxyprogesterone 17-n-caproate in habitual abortion. Annals of the New York Academy of Sciences 195871 762-786. (doi:10.1111/j.1749-6632.1958.tb46806.x)

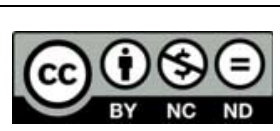

This work is licensed under a Creative Commons Attribution-NonCommercial-NoDerivs 4.0 International License. 
34 Shearman RP \& Garrett WJ. Double-blind study of effect of 17-hydroxyprogesterone caproate on abortion rate. BMJ 19631 292-295. (doi:10.1136/bmj.1.5326.292)

35 Eichner E \& Kunin K. The use of large doses of progesterone in delaying the onset of labor after premature spontaneous rupture of the membranes. American Journal of Obstetrics and Gynecology 195161 653-656.

36 Eichner E, Kunin K, Linden M, Goldberg I, Salinger L \& Peller Z. The use of large doses of progesterone in delaying the onset of labor after premature spontaneous rupture of the membranes. II. American Journal of Obstetrics and Gynecology 195467 339-341.

37 Fuchs F \& Stakemann G. Treatment of threatened premature labor with large doses of progesterone. American Journal of Obstetrics and Gynecology 196079 172-176.

38 Meis PJ, Klebanoff M, Thom E, Dombrowksi MP, Sibai B, Moawad AH, Spong CY, Hauth JC, Miodovnik M, Varner MW et al. Prevention of recurrent preterm delivery by $17 \alpha$-hydroxyprogesterone caproate. New England Journal of Medicine 2003348 2379-2385. (doi:10.1056/ NEJMoa035140)

39 Reinisch JM, Ziemba-Davis M \& Sanders SA. Hormonal contributions to sexually dimorphic behavioral development in humans. Psychoneuroendocrinology 199116 213-278. (doi:10.1016/0306-4530 (91)90080-D)

40 Silver RI, Rodriguez R, Chang TS \& Hearheart JP. In vitro fertilization is associated with an increased risk of hypospadias. Journal of Urology 1999 161 1954-1957. (doi:10.1016/S0022-5347(05)68863-5)

41 Carmichael SL, Shaw GM, Laurent C, Croughan MS, Olney RS \& Lammer EJ. Maternal progestin intake and risk of hypospadias. Archives of Pediatrics \& Adolescent Medicine 2005159 957-962. (doi:10.1001/ archpedi.159.10.957)

42 Romero R \& Stanczyk FZ. Progeterone is not the same as $17 \alpha$ hydoxyprogesterone caproate: Implications for obstetrical practice. American Journal of Obstetrics and Gynecology 2013208 421-426. (doi:10. 1016/j.ajog.2013.04.027)

43 Schmouder VM, Prescott GM, Franco A \& Fan-Havard P. The rebirth of progesterone in the prevention of preterm labor. Annals of Pharmacotherapy 201347 527-536. (doi:10.1345/aph.1R281)

44 Rode L, Langhoff-Roos J, Andersson C, Dinesen J, Hammerum MS, Mohapeloa H \& Tabor A. Systematic review of progesterone for the prevention of preterm birth in singleton pregnancies. Acta Obstetricia et Gynecologica Scandinavica 200988 1180-1189. (doi:10.3109/ 00016340903280982)

45 da Fonseca EB, Bittar RE, Carvalho MH \& Zugaib M. Prophylactic administration of progesterone by vaginal suppository to reduce the incidence of spontaneous preterm birth in women at increased risk: a randomized placebo-controlled double-blind study. American Journal of Obstetrics and Gynecology 2003188 419-424. (doi:10.1067/ mob.2003.41)

46 Rouse DJ, Caritis SN, Peaceman AM, Sciscione A, Thom EA, Spong CY, Carner M, Malone F, Iams JD, Mercer BM et al. A trial of $17 \alpha-$ hydroxyprogesterone caproate to prevent prematurity in twins New England Journal of Medicine 2007357 454-461. (doi:10.1056/ NEJMoa070641)

47 Caritis SN, Simhan HN, Zhao Y, Rouse DJ, Peaceman AM, Sciscione A, Spong CY, Varner MW, Malone FD, Iams JD et al. Relationship between 17-hydroxyprogesterone caproate concentrations and gestational age at delivery in twin gestation. American Journal of Obstetrics and Gynecology 2012207 396.e1-8. (doi:10.1016/j.ajog.2012.08.001)

48 Combs CA, Garite T, Maurel K, Das A \& Porto M. Failure of 17-hydroxyprogesterone to reduce neonatal morbidity or prolong triplet pregnancy: a double-blind, randomized clinical trial. American Journal of Obstetrics and Gynecology 2010203 e241-e249. (doi:10.1016/j. ajog.2010.06.016)

49 Rai P, Rajaram S, Goel N, Ayalur Gopalakrishnan R, Agarwal R \& Mehta S. Oral micronized progesterone for prevention of preterm birth.
International Journal of Gynaecology and Obstetrics 2009104 40-43. (doi:10.1016/j.ijgo.2008.08.029)

50 O'Brien JM, Adair CD, Lewis DF, Hall DR, Defranco EA, Fusey S, SomaPillay P, Porter K, How H, Schackis R et al. Progesterone vaginal gel for the reduction of recurrent preterm birth: primary results from a randomized, double-blind, placebo-controlled trial. Ultrasound in Obstetrics \& Gynecology 200730 687-696. (doi:10.1002/uog.5158)

51 Fonseca EB, Celik E, Parra M, Singh M \& Nicolaides KH. Progesterone and the risk of preterm birth among women with a short cervix. New England Journal of Medicine 2007357 462-469. (doi:10.1056/ NEJMoa067815)

52 Hassan SS, Romero R, Vidyadhari D, Fusey S, Baxter JK, Khandelwal M, Vijayaraghavan J, Trivedi Y, Soma-Pillay P, Sambarey P et al. Vaginal progesterone reduces the rate of preterm birth in women with a sonographic short cervix: a multicenter, randomized, double-blind, placebo-controlled trial. Ultrasound in Obstetrics \& Gynecology 201138 18-31. (doi:10.1002/uog.9017)

53 Conde-Agudelo A, Romero R, Nicolaides K, Chaiworapongsa T, O'Brien JM, Cetingoz E, da Fonseca E, Creasy G, Soma-Pillay P, Fusey S et al. Vaginal progesterone vs. cervical cerclage for the prevention of preterm birth in women with a sonographic short cervix, previous preterm birth, and singleton gestation: a systematic review and indirect comparison metaanalysis. American Journal of Obstetrics and Gynecology 2013208 42e1-42e18. (doi:10.1016/j.ajog.2012.10.877)

54 Norman JE, Mackenzie F, Owen P, Mactier H, Hanretty K, Cooper S Calder A, Mires G, Danielian P, Sturgiss S et al. Progesterone for the prevention of preterm birth in twin pregnancy (STOPPIT): a randomised, double-blind, placebo-controlled study and metaanalysis. Lancet 2009373 2034-2040. (doi:10.1016/S0140-6736 (09)60947-8)

55 Rode L, Klein K, Nicolaides KH, Krampl-Bettelheim E \& Tabor A Prevention of preterm delivery in twin gestations (PREDICT): a multicenter, randomized, placebo-controlled trial on the effect of vaginal micronized progesterone. Ultrasound in Obstetrics \& Gynecology 201138 272-280. (doi:10.1002/uog.9093)

56 Romero R, Espinoza J, Goncalves LF, Kusanovic JP, Friel LA \& Nien JK. Inflammation in preterm and term labour and delivery. Seminars in Fetal \& Neonatal Medicine 200611 317-326. (doi:10.1016/j.siny.2006. 05.001)

57 Allport VC, Pieber D, Slater DM, Newton R, White JO \& Bennett PR. Human labour is associated with nuclear factor- $\kappa \mathrm{B}$ activity which mediates cyclo-oxygenase- 2 expression and is involved with the 'functional progesterone withdrawal'. Molecular Human Reproduction 20017 581-586. (doi:10.1093/molehr/7.6.581)

58 Loudon JA, Elliott CL, Hills F \& Bennett PR. Progesterone represses interleukin- 8 and cyclo-oxygenase- 2 in human lower segment fibroblast cells and amnion epithelial cells. Biology of Reproduction 200369 331-337. (doi:10.1095/biolreprod.102.013698)

59 Cakmak H, Schatz F, Huang ST, Buchwalder L, Rahman M, Arici A \& Lockwood CJ. Progestin suppresses thrombin- and interleukin$1 \beta$-induced interleukin-11 production in term decidual cells: implications for preterm delivery. Journal of Clinical Endocrinology and Metabolism 200590 5279-5286. (doi:10.1210/jc.2005-0210)

60 Facchinetti F, Dante G, Venturini P, Paganelli S \& Volpe A. $17 \alpha$ Hydroxy-progesterone effects on cervical proinflammatory agents in women at risk for preterm delivery. American Journal of Perinatology 200825 503-506. (doi:10.1055/s-0028-1085071)

61 Speroff L \& Darney PD 2011 In A Clinical Guide for Contraception, 5th edn. Philadelphia: Wolters Kluwer Health/Lippincott Williams \& Wilkins.

62 Northen AT, Norman GS, Anderson K, Moseley L, Divito M, Cotroneo M, Swain M, Bousleiman S, Johnson F, Dorman K et al. Follow-up of children exposed in utero to $17 \alpha$-hydroxyprogeterone caproate compared with placebo. Obstetrics and Gynecology 2007110 865-872. (doi:10.1097/01.AOG.0000281348.51499.bc) 
63 Edelman AB, Cherala G \& Stanczyk FZ. Metabolism and pharacokinetics of contaceptive steroids in obese women: A review. Contraception 201082 314-323. (doi:10.1016/j.contraception.2010.04.016)

64 Bamberger CM, Else T, Bamberger AM, Beil FU \& Schulte HM. Dissociative glucocorticoid activity of medroxyprogesterone acetate in normal human lymphocytes. Journal of Clinical Endocrinology and Metabolism 199984 4055-4061. (doi:10.1210/jcem.84.11.6091)

65 Bhattacharya SM \& Jha A. Comparative study of the therapeutic effects of oral contraceptive pills containing desogestrel, cyproterone acetate, and drospirenone in patients with polycystic ovary syndrome. Fertility and Sterility 201298 1053-1059. (doi:10.1016/j.fertnstert.2012. 06.035)

66 Lahteenmaki P, Rauramo I \& Backman T. The levonorgestrel intrauterine system in contraception. Steroids 200065 693-697. (doi:10.1016/S0039-128X(00)00176-8)

67 Rivera R, Yacobson I \& Grimes D. The mechanism of action of hormonal contraceptives and intrauterine contraceptive devices. American Journal of Obstetrics and Gynecology 1999181 1263-1269. (doi:10.1016/S0002-9378(99)70120-1)

68 Natavio MF, Taylor D, Lewis RA, Blumenthal P, Felix JC, Melamed A, Gentzschein E, Stanczyk FZ \& Mishell DR. Temporal changes in cervical mucus after insertion of the levonorgestrel-releasing intrauterine system. Contraception 201387 426-431. (doi:10.1016/j.contraception. 2012.09.034

69 Kirkman-Brown JC, Bray C, Stewart PM, Barratt CL \& Publicover SJ. Biphasic elevation of $[\mathrm{Ca}(2+)](\mathrm{i})$ in individual human spermatozoa exposed to progesterone. Developmental Biology 2000222 326-335. (doi:10.1006/dbio.2000.9729)

70 Harper CV, Barratt CL \& Publicover SJ. Stimulation of human spermatozoa with progesterone gradients to simulate approach to the oocyte. Induction of $[\mathrm{Ca}(2+)](\mathrm{i})$ oscillations and cyclical transitions in flagellar beating. Journal of Biological Chemistry 2004279 46315-46325. (doi:10.1074/jbc.M401194200)

71 Correia JN, Conner SJ \& Kirkman-Brown JC. Non-genomic steroid actions in human spermatozoa. "Persistent tickling from a laden environment". Seminars in Reproductive Medicine 200725 208-219. (doi:10.1055/s-2007-973433)

72 Trussell J. Contraceptive failure in the United States. Contraception 2011 83 397-404. (doi:10.1016/j.contraception.2011.01.021)

73 Apter D, Gemzell-Danielsson K, Hauck B, Rosen K \& Zurth C. Pharmacokinetics of two low-dose levonorgestrel-releasing intrauterine systems and effects on ovulation rate and cervical function: pooled analyses of phase II and III studies. Fertility and Sterility 2014101 1656-1662 (e1654). (doi:10.1016/j.fertnstert.2014.03.004)

74 American College of Obstetricians and Gynecologists. ACOG Committee Opinion no. 450: Increasing use of contraceptive implants and intrauterine devices to reduce unintended pregnancy. Obstetrics and Gynecology 2009114 1434-1438. (doi:10.1097/AOG. Ob013e3181c6f965)

75 Ewies AA. Levonorgestrel-releasing intrauterine system-the discontinuing story. Gynecological Endocrinology 200925 668-673. (doi:10.1080/09513590903159656)

76 Moes JA \& Casey PM. Association of age and levonorgestrel intrauterine system removal for side effects in U.S. women. Obstetrics and Gynecology 2014123 12S. (doi:10.1097/01.AOG.0000447258.48749.40)

77 Jacobstein R. Long-acting and permanent contraception: an international development, service delivery perspective. Journal of Midwifery \& Women's Health 200752 361-367. (doi:10.1016/j.jmwh.2007.01.001)

78 Robinson N, Moshabela M, Owusu-Ansah L, Kapungu C \& Geller S. Barriers to intrauterine device uptake in a rural setting in Ghana. Health Care for Women International 2014 [in presss]. (doi:10.1080/07399332. 2014.946511)

79 Glasier AF, Cameron ST, Fine PM, Logan SJ, Casale W, Van Horn J, Sogor L, Blithe DL, Scherrer B, Nathe $\mathrm{H}$ et al. Ulipristal acetate versus levonorgestrel for emergency contraception: A randomised non-inferiority trial and meta-analysis. Lancet 2010375 555-562. (doi:10.1016/S0140-6736(10)60101-8)

80 Glasier A, Cameron ST, Blithe D, Scherrer B, Mathe H, Levy D, Gainer E \& Ulmann A. Can we identify women at risk of pregnancy despite using emergency contraception? Data from randomized trials of ulipristal acetate and levonorgestrel Contraception 201184 363-367. (doi:10. 1016/j.contraception.2011.02.009)

81 Madden T, Proehl S, Allsworth JE, Secura GM \& Peipert JF. Naproxen or estradiol for bleeding and spotting with the levonorgestrel intrauterine system: a randomized controlled trial. American Journal of Obstetrics and Gynecology 2012206 e121-e128. (doi:10.1016/j.ajog.2011.09.021)

82 Warner P, Guttinger A, Glasier AF, Lee RJ, Nickerson S, Brenner RM \& Chritchley HO. Randomized placebo-controlled trial of CDB-2914 in new users of a levonorgestrel-releasing intrauterine system shows only short-lived amelioration of unscheduled bleeding. Human Reproduction 201025 345-353. (doi:10.1093/humrep/dep377)

83 Lal S, Kriplani A, Kulshrestha V, Sharma M \& Agarwal N. Efficacy of mifepristone in reducing intermenstrual vaginal bleeding in users of the levonorgestrel intrauterine system. International Journal of Gynaecology and Obstetrics 2010109 128-130. (doi:10.1016/j.ijgo.2010.01.015)

84 Pitts SA, Feldman HA, Dorale A \& Gordon CM. Bone mineral density, fracture, and vitamin $\mathrm{D}$ in adolescents and young women using depot medroxyprogesterone acetate. Journal of Pediatric and Adolescent Gynecology 201225 23-26. (doi:10.1016/j.jpag.2011.07.014)

85 Heffron R, Donnell D, Rees H, Celum C, Mugo N, Were E, de Bruyn G, Nakku-Joloba E, Ngure K, Kiarie J et al. Use of hormonal contraceptives and risk of HIV-1 transmission: a prospective cohort study. Lancet. Infectious Diseases 201212 19-26. (doi:10.1016/S1473-3099 (11)70247-X)

86 Ziglar S \& Hunter TS. The effect of hormonal oral contraception on acquisition of peak bone mineral density of adolescents and young women. Journal of Pharmacy Practice 201225 331-340. (doi:10.1177/ 0897190012442066)

87 Boardman HM, Hartley L, Eisinga A, Main C, Roqué i Figuls M, Bonfill Cosp X, Gabriel Sanchez R \& Knight B. Hormone therapy for preventing cardiovascular disease in post-menopausal women. Cochrane Database Systematic Reviews 20153 CD002229. (doi:10.1002/ 14651858.CD002229.pub4)

88 Fournier A, Mesrine S, Boutron-Ruault MC \& Clavel-Chapelon F. Estrogen-progestagen menopausal hormone therapy and breast cancer: does delay from menopause onset to treatment initiation influence risks? Journal of Clinical Oncology 200927 5138-5143. (doi:10.1200/ JCO.2008.21.6432)

89 Bender NM, Segall-Gutierrez P, Najera SO, Stanczyk FZ, Montoro M \& Mishell DR Jr. Effects of progestin-only long-acting contraception on metabolic markers in obese women. Contraception 201388 418-425. (doi:10.1016/j.contraception.2012.12.007)

90 Centers for Disease Control and Prevention (CDC). U S Medical Eligibility Criteria for Contraceptive Use, 2010. MMWR Recommendations and Reports 59(RR-4) 1-86. (available at: http://www.cdc.gov/ mmwr/preview/mmwrhtml/rr5904a1.htm)

91 Weiderpass E, Adami HO, Baron JA, Magnusson C, Bergström R, Lindgren A, Correia N \& Persson I. Risk of endometrial cancer following estrogen replacement with and without progestins. Journal of the National Cancer Institute 199991 1131-1137. (doi:10.1093/jnci/91.13. 1131)

92 Hubacher D, Lopez L, Steiner MJ \& Dorflinger L. Menstrual pattern changes from levonorgestrel subdermal implants and DMPA: Systematic review and evidence-based comparisons. Contraception 2009 80 113-118. (doi:10.1016/j.contraception.2009.02.008)

93 Tibbetts TA, Conneely OM \& O'Malley BW. Progesterone via its receptor antagonizes the pro-inflammatory activity of estrogen in the mouse uterus. Biology of Reproduction 199960 1158-1165. (doi:10.1095/ biolreprod60.5.1158)

94 Kleynhans L, Du Plessis N, Allie N, Jacobs M, Kidd M, van Helden OD, Walzl G \& Ronacher K. The contraceptive depot

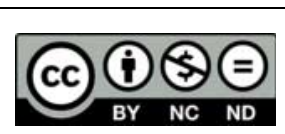

This work is licensed under a Creative Commons Attribution-NonCommercial-NoDerivs 4.0 International License. 
medroxyprogesterone acetate impairs mycobacterial control and inhibits cytokine secretion in mice infected with Mycobacterium tuberculosis. Infection and Immunity 201381 1234-1244.

(doi:10.1128/IAI.01189-12)

95 Tomasicchio M, Avenant C, Du Toit A, Ray RM \& Hapgood JP. The progestin-only contraceptive medroxyprogesterone acetate, but not norethisterone acetate, enhances HIV-1 Vpr-mediated apoptosis in human CD4+T cells through the glucocorticoid receptor. PLoS ONE 20138 e62895. (doi:10.1371/journal.pone.0062895)
96 Velez-Ortega AC, Temprano J, Reneer MC, Ellis GI, McCool A, Garnder T, Khosravi M \& Marti F. Enhanced generation of suppressor T cells in patients with asthma taking oral contraceptives. Journal of Asthma 201350 223-230. (doi:10.3109/02770903.2012.761231)

97 Africander D, Louw R, Verhoog N, Noeth D \& Hapgood JP. Differential regulation of endogenous pro-inflammatory cytokine genes by medroxyprogesterone acetate and norethisterone acetate in cell lines of the female genital tract. Contraception 201184 423-435. (doi:10.1016/j. contraception.2011.06.006)

Received in final form 22 September 2015

Accepted 6 October 2015
This work is licensed under a Creative Commons Attribution-NonCommercial-NoDerivs 4.0 International License. 